University of Minnesota Morris Digital Well

University of Minnesota Morris Digital Well

7-6-2017

\title{
Librarian on the Loose: A Roving Reference Desk at a Small Liberal Arts College
}

Peter Bremer

University of Minnesota - Morris, pbremer@morris.umn.edu

Follow this and additional works at: https://digitalcommons.morris.umn.edu/library

Part of the Library and Information Science Commons

\section{Recommended Citation}

Bremer, Peter. "Librarian on the Loose: A Roving Reference Desk at a Small Liberal Arts College." The Reference Librarian 58.1 (2017): 106-110.

This Article is brought to you for free and open access by the Faculty and Staff Scholarship at University of Minnesota Morris Digital Well. It has been accepted for inclusion in Library Publications by an authorized administrator of University of Minnesota Morris Digital Well. For more information, please contact skulann@morris.umn.edu. 


\title{
Librarian on the Loose: A Roving Reference Desk at a Small Liberal Arts College
}

\author{
Peter Bremer
}

If our reference desk had an odometer it would have rolled over several times by now. Since 2008 the University of Minnesota, Morris (UMM) Briggs Library has provided a roving reference service called Librarian on the Loose to help promote research assistance on campus. Several times a week I venture out, rain or shine, a laptop draped over my shoulder, and set up a conspicuous table in a high-traffic area. I am usually the only staff member in a sea of students. Before long, I am engaging with passer-byes. Some of them have never set foot in our library. This is an important point since a roving librarian program serves "clientele whom traditional reference sometimes does not reach" (Kramer, 1996).

Roaming reference is not new, of course. Staff in academic and public library settings have been venturing out from behind the desk in different ways for some time. According to McCabe and MacDonald (2011), roaming reference is "used to describe services provided in a non-traditional manner: roving, outpost, offsite and point of need reference services. In essence, it is anything occurring away from the confines of the reference desk."

Walking the floors and aisles during a reference shift is one thing, and is fraught with its own set of unique challenges, but moving, even temporarily to another location, is another matter. A roving librarian program, done well, requires time and effort. "The implementation and execution of roaming services require extensive planning, taking service hours, location, approach, evaluation, technology, training and staffing into consideration" (McCabe).

Thankfully, the wonders of technology have made the prospect of setting up a mobile reference desk much simpler. All you really need is a laptop or tablet. Don't have access to one 
of those? That's all right. Smartphones have put the power of a computer into our hands. Even so, the practice of roving reference is far from widespread and often doesn't get the attention it deserves. This is a shame since a program featuring librarians on the move can engage in conversations that desk-bound counterparts are hard-pressed to match and can increase reference service visibility.

Those of us in the library community are all too aware that reference transactions have, in general, been decreasing. In Rachel Applegate's article "Whose Decline?" she notes that reference transactions in academic libraries have been declining when the most commonly used measures of reference activity are applied, although she notes that institutional type and other factors can moderate this, resulting in some libraries experiencing an increase (2008).

At Briggs Library we have experienced a drop of over $20 \%$ in overall reference transactions since 2005, even as our virtual reference offerings such as chat have grown modestly. This works out to be about a $2.2 \%$ annual decrease, which happens to be the figure cited by Applegate in regard to the approximate drop in reference transactions when comparing Academic Libraries Survey data from 2002 and 2004 for an average academic library in the United States.

Although the exact reasons for the decline in reference activity are unclear we can perhaps look to the ease of searching online as a likely contributor as well as ordinary human behavior. It's always been difficult for patrons to ask for help. As librarians we're aware of the fact that some students or community members rarely, if ever, venture into the physical library. Some may not even use our virtual resources regularly. Other individuals may have a limited perception of what the library has to offer. A few may even have a negative view of libraries or librarians based on some earlier encounter. As the Librarian on the Loose it has always been my 
primary goal to help promote reference services and be an ambassador of goodwill for the library. Along the way I try to have some fun too.

Three times a week, in the morning or afternoon, I strike out across our small undergraduate liberal arts campus of approximately 1800 students and set-up a mobile reference desk. Favorite spots of mine include our campus Student Center and Dining Services as well as a lounge located in the Multi-Ethnic Resource Center (MRC). In January of 2015 I tested the waters and began visiting one of our residence halls where a student mentoring program has a tutoring area. Prior to establishing these spots I contacted the respective offices and communicated my intentions to make sure my visit would be supported.

Choosing the right spot is crucial. High traffic areas are important for visibility. Both the Student Center and the Dining Services lobby at UMM are usually packed with people. In addition, the lounge in the our Multi-Ethnic Resource Center is a favorite spot for students of color to study and socialize while the room in the Blakely residence hall often has program tutors meeting with students who come from disadvantaged backgrounds. It's worth noting that UMM has a population of over $25 \%$ students of color. In addition, a sizable proportion of our students our first-generation college students. By going to these varied locations on campus I am able to engage with students in social situations as well as more studious environments and help them acclimate to college life. Future prospects might include academic buildings and computer labs. The important thing is to be where your patrons are, whether they're grabbing a quick bite to eat, walking between classes or working on a research paper.

Timing is everything. Picking the right hour of the day can make the difference between having tons of student contact and tabling in an empty space. At UMM, some areas like the Student Center can thin out later in the day while our Dining Services is most active around meal 
times. Be observant! I usually schedule my visits to the MRC lounge in the afternoon, after most classes are finished. Remember to stay flexible! Because my original residence hall time was a little too quiet, I ended up changing it to the morning when more tutors were present.

First impressions matter. Once I've walked to my Librarian on the Loose location the next step is setting up the roving reference desk. Besides bringing a laptop so I can answer questions I also have signage, candy, and a short quiz. I call it the Librarian on the Loose Quiz of Ultimate Fun. Each month a new set of questions is featured based on a theme. Connecting a topic with a library/campus event or a national news item is a great way to enlarge the conversation. Past examples include: Minnesota weather, politics, Halloween, Native American history, Briggs Library collections, Irish history, Minnesota music, health and nutrition, art, famous comedians, superheroes, banned books, aviation, cartoon characters, and literature. Scores don't matter. Taking the quiz simply serves as the way to enter the drawing, although I do share the answers with students. An individual earning a top score gets bragging rights. After the quiz students can enter the drawing to win a $\$ 10.00$ gift certificate good at our campus coffee shop. This has proved very popular and is an enticement for students to come over or return the following month. I often have individuals stop and ask when I will have a new quiz, say hello or ask a reference question. Students look forward to my visits and I would like to think the service brightens their day. I'm often greeted with the familiar refrain of 'Hey, you're on the loose again!' To which I usually reply, "I just hope they let me back in again.” Before they leave I invite students to take a piece of candy.

Stay awhile. As a general rule I usually stay in one location at least an hour to an hour and a half. Anything less than this is generally not worth the effort of travel and set-up. If it is especially busy and my schedule is accommodating I will try and stay a little bit longer. 
Act like you want to be there. I'm generally a pretty gregarious person, but when I'm tabling for Librarian on the Loose I need to kick it up a notch. Being a well-meaning wallflower staring at a computer screen won't cut it. When out and about try and be proactive and engage with students and staff as they amble by. Being open and having a sense of humor pays dividends in making you more approachable. Every individual engaged with is one more person who will hopefully be more inclined to use the library and ask for help.

Roaming reference takes a measure of planning and commitment. Each month I create a new quiz, make copies, and purchase candy as well as a gift card. The laptop also needs to be charged weekly. A daily schedule already bursting at the seams becomes even more crammed when an extra roaming reference desk shift is factored in. Although UMM is relatively small, trekking across campus in the rain or the cold can make it feel a whole lot bigger. There are days when I look forward to getting out of the insular library, and others when it can feel more like a burden. Sometimes all the planning in the world is for naught and an unexpected meeting or crisis will cause me to cancel a Librarian on the Loose reservation. Priority is always given to the regular reference desk.

With any service ample publicity must be done so people are made aware of it. For my Librarian on the Loose initiative I advertise on our digital signage screens, RSS news feeds, Facebook and Twitter accounts as well as occasional posters. I also have a library webpage with more information including current semester hours and locations. In the past, I have used images featuring me "escaping" from the library in special marketing efforts. I also enlisted one of our library work-study students to create a large sign that I could put up when tabling. Next year I plan on designing a custom baseball cap so I can better advertise the Librarian on the Loose service when out of the library. Be creative! 
How successful has our roving librarian initiative been? For the last five years we have tracked reference questions using Gimlet. Each semester I have averaged about a dozen reference questions while on the "loose". Most of these have been research related. What this modest figure fails to show, however, is the number of individuals who have had a positive experience with a librarian. In the past seven years I have engaged with hundreds of students and staff across campus, bringing the library to a wider audience, building relationships beyond our walls, and promoting reference services. By that measure, our roaming librarian initiative has been an unqualified success.

At its most fundamental level a roaming librarian program can act as an ambassador. According to Lavoie a roaming librarian has the ability to foster "personal and friendly contact outside the library building, [which] is especially significant for students who are new to college and may have perceived their high school library as a passive space where students go only when they need information" (2008).

Another tangible benefit is the ability to better gauge what is happening on campus or in your community by being in the midst of it, instead of stuck behind four walls. Countless times I've had serendipitous conversations with students or staff that might not have occurred in a more traditional setting. Being in the right place at the right time can pay dividends in unexpected ways. It's also vital to think outside of the box. Our patrons, especially younger ones, expect it.

In Barnhart and Pierce's (2011) article they offer the following advice. "It is important for reference librarians to explore ways in which wireless and mobile technologies can extend inperson services, such as roving or embedded librarians, as we strive to make our libraries' service more ubiquitous." Such a goal is never-ending, of course, but in making the effort we 
take an important step in recognizing that the library can be a vibrant place reaching out to its community of users rather than a passive institution.

Libraries can also play a role in fostering connections with students, especially first-year students, in order to provide additional support and stability in their transition from high school to college. Tinto notes in Leaving College that the largest proportion of institutional leaving occurs in the first year (1993). He also makes it clear that student retention is not the province of a specific program, but rather "the responsibility of all members of an institution, faculty and staff alike" (1993). By strengthening and expanding relationships with students beyond the confines of the library, a roving librarian program can enhance, in some small way, the overall retention strategies of an institution. Each of us can play a part. Research suggests that by facilitating meaningful, out-of-class interactions with staff and faculty as well as helping students navigate the campus academic libraries can position themselves to be pivotal players in campus efforts to acculturate students (Grallo 2012).

So while Briggs Library's reference statistics, like many other institutions, have declined over the years, the Librarian on the Loose program has increased awareness of our services, broadened our connections across our campus, and perhaps in a small way, moderated any decrease in desk assistance by strengthening a perception of the library as a vital and outgoing institution willing and eager to meet our patrons halfway. 


\section{References}

Applegate, R. (2008). Whose decline? Which academic libraries are "deserted" in terms of reference transactions? Reference \& User Services Quarterly, 176-189.

Barnhart, F. D., \& Pierce, J. E. (2012). Becoming mobile: Reference in the ubiquitous library. Journal of Library Administration, 52(6-7), 559-570. doi:

$0.1080 / 01930826.2012 .707954$

Grallo, Jacqui D. (2012) How do I get a campus ID? The other role of the academic library in student retention and success. The Reference Librarian, 53(2), 182-193. doi:

$10.1080 / 02763877.2011 .618787$

Kramer, Eileen H. (1996). Why Roving Reference: A Case Study in a Small Academic Library. Reference Services Review, 24(3), 67-80. doi: $\underline{\text { http://dx.doi.org/10.1108/eb049290 }}$

Lavoie, L. (2008). Roving librarians: taking it to the streets. Urban Library Journal, 15(1). Retrieved from http://academicworks.cuny.edu/ulj/vol15/iss1/8/

McCabe, K. M., \& MacDonald, J. R. (2011). Roaming reference: Reinvigorating reference through point of need service. Partnership: The Canadian Journal of Library and Information Practice and Research, 6(2). Retrieved from https://journal.lib.uoguelph.ca/index.php/perj/article/viewArticle/1496\#.VzH5jubzPZe

Tinto, V. (1993). Leaving College: Rethinking the Causes and Cures of Student Attrition. Chicago: University of Chicago Press. 